\title{
Methodology for assessing the relative tourist attractiveness of the region
}

\author{
Ekaterina Yakimova*, Anastasiya Rusina, Olga Karpycheva \\ Siberian Federal University, 79 Svobodny pr., 660041 Krasnoyarsk, Russia
}

\begin{abstract}
Assessment of the tourist attractiveness of a territory is an important analytical area in terms of identifying opportunities for development of regional tourism, as one of the most significant and promising sectors of the economy. This can be the basis for development of appropriate strategic regional programs. The existing scientific discussion in this area has contributed to emergence of a number of methodological approaches that can be used in practice. However, their critical analysis revealed a number of provisions, the improvement of which will make it possible to obtain more objective and relevant results, reflecting the possibility of the destination becoming an object of attraction for tourists. Firstly, the lack of a clear distinction between the categories of "tourist potential", which reflects the objective state of the resources of the territory, and "tourist attractiveness", which includes the estimated component of available resources from the perspective of a consumer of tourist services. This leads to the fact that the principle of the subjectivity of the assessment is practically not implemented, thus the possibility of focusing on market demands is not fully used, which implies use of segmentation and positioning tools. Secondly, the results obtained using the methods offered by the scientific community are often distorted by the subjective perception of the researcher, which is associated with use of a large volume of expert assessments. Thirdly, from our point of view, the number of estimated variables, the number of which may approach 100, is not always justified. This, on the one hand, reduces the degree of influence of each of them on the result, and, therefore, the significance, and on the other hand, makes it difficult for the analyst to collect the necessary information. Therefore, the purpose of this study is to develop a methodology that eliminates these disadvantages. The offered author's development includes objective indicators that do not require involvement of experts in their assessment. The number of these indicators is limited and systematized by groups, in accordance with modern market demands: directly attracting tourists, ensuring the quality of stay and ensuring the availability of the territory. The relative form of the offered metrics shows the degree of difference in the selected variables of some territories in comparison with others, which in the future will make it possible to orient the tourism development in the region to target audiences whose needs can be satisfied by the resources available at the destination.
\end{abstract}

\footnotetext{
${ }^{*}$ Corresponding author: eyakimova@sfu-kras.ru
} 


\section{Introduction}

Tourism is the most important industry due to the inherent multiplier effect on development of the economy, both in the country as a whole and in individual regions. Development of this sector ensures diversification of the territory's economy, contributing to the positive dynamics of related industries. The regularity of the increase in the standard of population living in the regions where the tourist potential is effectively implemented is noted, which indicates the beneficial effect of this sphere on the general well-being of the population of the territory. Also, formation of tourist activity ensures the growth of additional jobs, and etc. It shall be noted that contribution of tourism to the world GDP by 2019 reached $10.4 \%$ [1]. For $38 \%$ of countries, tourism is the main source of income, and for $83 \%$ of countries, tourism is among the top five. In Russia, this indicator is significantly lower in 2019 at 3.9\%, and although it tends to grow (increased by $0.9 \%$ since 2011 ) [1], it clearly lags behind the global average value. The underlying reason for this state of the tourism industry is the ineffective implementation of the existing tourism potential, which is objectively assessed quite high. There are clear prerequisites for obtaining a higher level of contribution of this industry to the economy of the country and regions, which, among other things, include the number of World Heritage sites (18 sites and 10th place in the world ranking) and UNESCO World Natural Heritage (11 sites and 4th place in the world ranking) [10].

It is worth noting that in the modern conditions of antiquated restrictions associated with international travel, special attention in the development of tourism shall be paid to measures to enhance internal tourist flows within regions and between regions. However, in order to implement this task, it is necessary to create an effective industry management system based on development of informed management decisions using high-quality information and analytical support. Such support will be created, inter alia, by a methodology for assessing the relative attractiveness of a territory, reflecting the current state of the existing tourist potential and the possibilities of tourism development based on its implementation in accordance with market demands. The developed author's methodology will make it possible to carry out a comparative assessment of the region attractiveness in the context of the identified key needs of the target audiences. An increase in tourist activity due to alignment of the existing tourist potential and consumer demands will improve the economic performance of the region and give an impetus to its development.

The problem of assessing the attractiveness of a tourist destination in the scientific reference has some coverage, a critical analysis of which made it possible to identify a number of patterns and presence of methodological gaps. Thus, a number of researchers, when offering to assess the tourist attractiveness of a territory, reduce it to an assessment of the tourist potential of a region, without assessing demand characteristics. Wherein, the list of indicators of tourist potential can be quite extensive, which creates a problem with obtaining the necessary information for conducting a study, and also reduces the significance of each indicator and the degree of its influence on the final result. Other researchers, on the contrary, rely solely on the results of the survey, without creating a methodological basis for carrying out this analytical work. The author's development is able to neutralize the specified disadvantages.

\section{Methods}

The paper uses the methods of system analysis, classification, comparison and modeling. In order to implement the choice of the most successful practices for developing approaches to assessing the tourist attractiveness of a territory, a comparison method was used. The system analysis made it possible to develop an approach to eliminating the problem of the lack of 
information and analytical support in the field of regional tourism management by offering a methodology for the relative assessment of the region attractiveness. The modeling method made it possible to identify the constituent elements of the factors that form the destination attractiveness. The classification method made it possible to systematize the studied methods of assessing the tourist potential according to the "basis of the methodological approach".

The tourist attractiveness of a region is a combination of its objective and subjective characteristics, material and intangible factors that affect the results of tourism activities and determine the position of the region for tourists and subjects of tourism activities, which includes the resource and infrastructure potential of tourism activities and the social and institutional risks of its implementation on this territory [3]. Unlike attractiveness, tourism potential is an objective category, since its size and the value of its qualities are assessed regardless of specific needs. Tourist potential is a spatio-temporal combination of natural, public and natural-public resources, reserves and opportunities for arranging and carrying out the tourist activities [4].

Wherein, the category potential has a dynamic character from the point of view of its assessment, which is reflected in Figure 1.

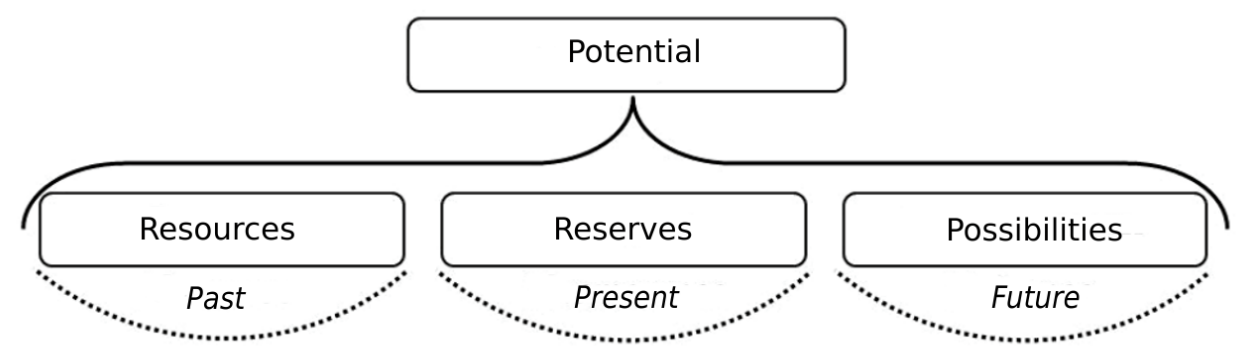

Fig. 1: Components of the concept of "potential" [3].

The relationship between the categories "tourist potential" and "tourist attractiveness" is shown in Figure 2.

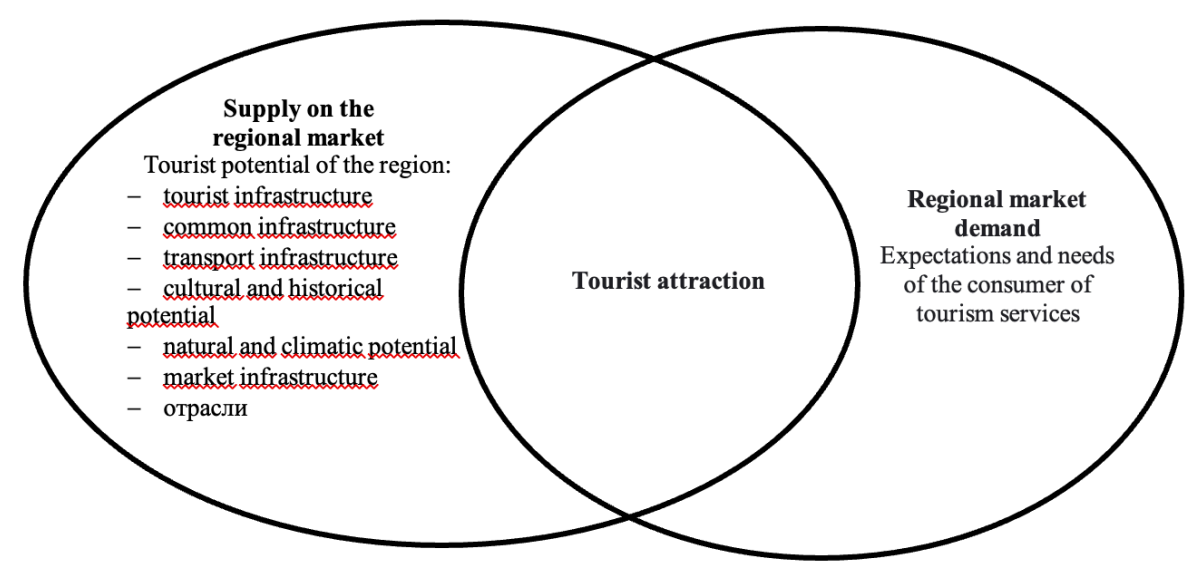

Fig. 2: Correlation of categories "tourist potential" and "tourist attractiveness" Source: [Compiled by the authors]. 
Despite the obvious difference in the definition of the essence of these categories, there is also a clear relationship between them. It is the existing potential of the destination that can and shall become the basis for formation of the region attractiveness the field of tourism. It is not surprising that the territory attractiveness is often offered to be assessed using the same factors as the tourist potential. In addition, it shall be noted that, in many respects, researchers dealing with the problem of assessing the recreational attractiveness of the territory reduce its analysis to the study of tourist potential, which also gives reason to include this analytical direction in the range of methods under consideration.

A critical analysis of the existing methods made it possible to form a classification of approaches and assess the possibilities of their application in practice to obtain initial data in order to make management decisions in the field of increasing the attractiveness of the tourism industry in the region. The results of the analysis are provided in Table 1.

Table 1. Classification of methodological approaches for assessing the tourist attractiveness of the region/territory.

\begin{tabular}{|c|c|c|}
\hline $\begin{array}{l}\text { Methodical } \\
\text { approach }\end{array}$ & Author's interpretation & $\begin{array}{l}\text { Identified shortcomings of } \\
\text { the author's approach }\end{array}$ \\
\hline \multirow[t]{3}{*}{$\begin{array}{l}\text { Calculation of } \\
\text { the integral } \\
\text { indicator }\end{array}$} & $\begin{array}{l}\text { Yu.D. Schmidt, E.I. Yuvanen [7] } \\
\text { It is the formation of } 4 \text { groups of factors - } \\
\text { transport accessibility, recreational and tourist } \\
\text { infrastructure, natural and ecological } \\
\text { attractiveness, the level of socio-economic } \\
\text { development of the territory - which, with the } \\
\text { help of expert assessments, were ranked and } \\
\text { evaluated on the basis of statistical information. }\end{array}$ & $\begin{array}{l}\text { Does not consider the } \\
\text { attractiveness of the territory } \\
\text { from the point of view of } \\
\text { individual target audiences } \\
\text { and their subjective } \\
\text { assessment. Use of expert } \\
\text { judgment can distort the result } \\
\text { obtained. }\end{array}$ \\
\hline & $\begin{array}{l}\text { A.N. Dunets, E.P. Krupochkin, A.A. Teltsova } \\
\text { [12] } \\
\text { Structuring the elements of the recreational and } \\
\text { tourist potential in three blocks (thematic } \\
\text { sections): natural conditions and resources, } \\
\text { cultural and historical factors, socio-economic } \\
\text { factors. To assess them, absolute (primary) and } \\
\text { relative (secondary) indicators are offered, on } \\
\text { the basis of which a cartographic GIS model is } \\
\text { built. }\end{array}$ & $\begin{array}{l}\text { Does not consider the } \\
\text { attractiveness of the territory } \\
\text { from the point of view of } \\
\text { individual target audiences } \\
\text { and their subjective } \\
\text { assessment. Use of expert } \\
\text { judgment can distort the result } \\
\text { obtained. }\end{array}$ \\
\hline & $\begin{array}{l}\text { M.V. Gudkovskikh [11] } \\
\text { Using the balance approach (method), it is the } \\
\text { formation of the income part of the balance due } \\
\text { to the blocks of natural factors, historical, } \\
\text { cultural, socio-economic, tourist, as well as the } \\
\text { expense one - due to unfavorable factors and } \\
\text { the ecological situation. Each block consists of } \\
\text { interrelated indicators, the assessment of which } \\
\text { is carried out in an expert way, by assigning } \\
\text { points. }\end{array}$ & $\begin{array}{l}\text { The methodology is not } \\
\text { focused on consumer needs. } \\
\text { So, a priori, some } \\
\text { characteristics are indicated } \\
\text { as an advantage (for example, } \\
\text { duration of the summer } \\
\text { period, presence of a } \\
\text { reservoir, and etc.), while } \\
\text { they may not meet the goals } \\
\text { and motives of the tourist (for } \\
\text { example, a ski vacation). Use } \\
\text { of expert judgment can distort } \\
\text { the result obtained. }\end{array}$ \\
\hline
\end{tabular}


Continuation of table 1.

\begin{tabular}{|c|c|c|}
\hline & $\begin{array}{l}\text { L.I. Kulakova, V.A. Osipov [13] } \\
\text { The main factors are highlighted: historical and } \\
\text { cultural potential, infrastructural potential, } \\
\text { potential of specially protected natural areas, } \\
\text { potential of natural conditions. On their basis, } \\
\text { relative indicators are formed, comparing the } \\
\text { result of assessing a certain territory with the } \\
\text { maximum possible value of a given region. The } \\
\text { method considers the parameter of the } \\
\text { territorial distance of the evaluated objects } \\
\text { (localization factor, distance correction factor). }\end{array}$ & $\begin{array}{l}\text { Scores are used to a large } \\
\text { extent, and although scales } \\
\text { are set to determine them, } \\
\text { there is nevertheless an } \\
\text { element of subjectivity. The } \\
\text { methodology is not focused } \\
\text { on consumer needs. }\end{array}$ \\
\hline & $\begin{array}{l}\text { D.G. Mamraeva, L.V. Tashenova [5] } \\
4 \text { subpotentials are distinguished: natural } \\
\text { conditions and resources, cultural and historical } \\
\text { resources, provision of tourist infrastructure, } \\
\text { information security of tourism, as well as } \\
\text { limiting factors that reflect the risks of a tourist } \\
\text { in the city. In total, } 97 \text { parameters were } \\
\text { identified in all blocks, which the authors } \\
\text { considered as the most significant. }\end{array}$ & $\begin{array}{l}\text { The excessive number of } \\
\text { parameters makes it difficult } \\
\text { to use the methodology. In } \\
\text { addition, influence of each } \\
\text { hotel indicator in this case is } \\
\text { insignificant on the final } \\
\text { result, at the level of error. } \\
\text { Also, the methodology is not } \\
\text { focused on consumer needs. }\end{array}$ \\
\hline $\begin{array}{l}\text { Use of single } \\
\text { indicators }\end{array}$ & $\begin{array}{l}\text { E.I. Bogdanov [6] } \\
\text { According to the methodology, it is offered to } \\
\text { distinguish between the following indicators: a) } \\
\text { the total volume of resources of the tourist } \\
\text { potential; b) the size of the tourist potential; c) } \\
\text { indicator of tourist potential implementation. A } \\
\text { quantitative expression of the potential can be a } \\
\text { certain number of tourists accommodated in a } \\
\text { certain territory without harming the } \\
\text { environment, population, cultural and historical } \\
\text { sites, the quality of recreation, as well as } \\
\text { development of other sectors of the economy. }\end{array}$ & $\begin{array}{l}\text { Does not consider the } \\
\text { attractiveness of the territory } \\
\text { from the point of view of } \\
\text { individual target audiences } \\
\text { and their subjective } \\
\text { assessment. The ability of the } \\
\text { territory to accommodate a } \\
\text { certain number of tourists } \\
\text { does not mean the actual } \\
\text { implementation of this value. }\end{array}$ \\
\hline \multirow[t]{2}{*}{$\begin{array}{l}\text { Qualitative } \\
\text { description of } \\
\text { the tourist } \\
\text { features of the } \\
\text { region }\end{array}$} & $\begin{array}{l}\text { U.A. Zagumennaya [14] } \\
\text { The study approach is based on the study of } \\
\text { types of tourism and the possibility of their } \\
\text { implementation in a certain tourist area due to } \\
\text { the existing quality characteristics. }\end{array}$ & $\begin{array}{l}\text { Absence of a specific } \\
\text { assessment methodology } \\
\text { reduces the possibility of a } \\
\text { comparative assessment of } \\
\text { the analyzed territories and } \\
\text { makes it difficult to compare } \\
\text { the study results. The degree } \\
\text { of subjectivity is high. }\end{array}$ \\
\hline & $\begin{array}{l}\text { I.S. Glebova [8] } \\
\text { The article provides a step-by-step process of } \\
\text { managing the attractiveness of the territory } \\
\text { (city) based on a qualitative analysis with } \\
\text { elements of statistical data. }\end{array}$ & $\begin{array}{l}\text { Absence of a specific } \\
\text { assessment methodology } \\
\text { reduces the possibility of a } \\
\text { comparative assessment of } \\
\text { the analyzed territories and } \\
\text { makes it difficult to compare } \\
\text { the study results. The degree } \\
\text { of subjectivity is high. }\end{array}$ \\
\hline $\begin{array}{c}\text { Assessment } \\
\text { using social } \\
\text { methods } \\
\text { (survey) }\end{array}$ & $\begin{array}{c}\text { E.V. Frolova, E.E. Kabanova [9] } \\
\text { A survey of experts in the field of tourism and } \\
\text { consumers made it possible to identify the main } \\
\text { problems of development of the territory } \\
\text { empirically. }\end{array}$ & $\begin{array}{c}\text { Lack of a universal } \\
\text { methodology that would } \\
\text { make it possible to use it for } \\
\text { other regions. Resource } \\
\text { intensity of the approach } \\
\text { implementation. }\end{array}$ \\
\hline
\end{tabular}

Source: [Compiled by the authors]. 
The analysis of the author's developments in this area made it possible to draw the following conclusions:

- the calculation of the integral indicator is the most elaborated and frequently used approach, since it allows to quantitatively reflect the attractiveness of the territory and makes it possible to compare it with other regions. Wherein, in most cases, a similar algorithm for formation of calculating the coefficient with some author's interpretation is offered;

- the above methods have a number of disadvantages, the key ones being the lack of their target orientation to the requests of individual segments of consumers of tourism services, as well as use of a significant list of assessed parameters (about 100) and a large amount of expert assessments, which reduces the relevance and objectivity of the results;

- the attractiveness of a destination is most often assessed by absolute indicators reflecting the actual state of climatic conditions, natural objects, the number of monuments, and etc., but they do not give an understanding of whether these characteristics of the tourist potential will really be objects of attraction for tourists.

The developed author's approach makes it possible to use a quantitative assessment of the attractiveness of a destination by calculating the author's indicator, but at the same time to level the indicated disadvantages.

\section{Results}

In an attempt to find the most effective way to integrate the territory into the system of internal tourist flows and increase their intensity, the main task is to identify the priority target audiences of consumers who would more easily and quickly respond to the activities being implemented, creating an impetus for further development of the tourism industry in the region.

Using the principle of focusing on the preferences of target segments in the methodology, we will use the following hypotheses:

- the main request of a tourist in meeting recreational needs is to change the usual environment and get new impressions;

- the choice of a tourist destination will depend on the formed motives of the representatives of the target audiences, therefore, the assessment of its attractiveness will differ in accordance with the characteristics of consumers.

The first thesis is based on a study [10], which demonstrated that the expectations of tourists are often associated with a request for a new emotional experience, with the desire to be in an unfamiliar environment for a vacation. It shall be noted that, according to the analysis of the opinions of consumers of tourism services, the unique intangible culture of the regions - music, cooking, dance, traditions, language, religion, crafts — ranks third in importance in terms of the region attractiveness after the natural and infrastructural potential [10], which is clearly underestimated in modern approaches to tourism development. Moreover, in terms of a positive assessment of the experience gained, intangible heritage ranks second after the natural component. Therefore, even the destinations, in the territories of which there are no significant cultural and historical sites, have the opportunity to attract tourist flows through development of natural potential, as well as by providing the opportunity to get new impressions, experiences and sensations. It shall be noted that many regions located in the European part of Russia - the most accessible for domestic tourism and rich in historical and cultural monuments - turned out to be not very popular with Russians. Among them, for example, Ivanovo, Novgorod, Pskov, Astrakhan, Orenburg, Saratov regions [10]. Therefore, even such regions, which were traditionally considered attractive for tourists, today shall rethink the concept of the offered tourist product.

The second thesis was formulated on the basis of an analysis of the possible motives of a tourist and the assumption that for different target audiences the priority and significance of 
the existing types of tourist potential of the territory will be different. Therefore, the authors of the article do not agree with the position of some researchers, who a priori determine the attractiveness of some tourist areas as unsatisfactory, and the territories themselves are unpromising for development of the tourism sector. Therefore, it is necessary to identify the existing requests of the Russian tourists and offer a product that meets their expectations, forming the specialization of the area.

We offer to systematize indicators of tourist potential into the following 3 groups: directly attracting tourists, ensuring the quality of stay and ensuring accessibility, and then, on their basis, assess the relative attractiveness of territories for tourists.

Attraction factors are the main driving force of tourist flows, which ensures the desire to visit a tourist location. Among the factors that directly attract tourists, we will include the following:

1) natural factors:

- average temperature (summer/winter);

- the type of landscape and the variety of relief, the contrast of the landscape;

- the share of the area of special territories in the region;

- the uniqueness of the biosphere.

2) historical and cultural factors:

- the presence of distinctive nationalities, possibly with a pronounced reservation effect, that have preserved a unique cultural code;

- social activity (festivals, fairs, holidays, and etc.);

- the number and degree of localization of objects of cultural and historical heritage;

- the historical value of the placed objects.

The factors providing a comfortable stay, according to the authors' logic, are not objects of attraction in themselves, but contribute to formation of the general impression of the tourist about the attractiveness of the destination. Among the factors that ensure the quality of stay, we will include:

1) accommodation infrastructure:

- the level of occupancy of hotels;

- provision of tourist flows with room stock;

2) general infrastructure:

- public catering turnover;

- retail trade turnover;

3) additional tourist services:

- travel agency services;

- guide services;

- transfer.

The factors ensuring accessibility are also not an object of attraction, but they are critically important from the point of view of the possibility of visiting a tourist location. These include:

1) transport infrastructure:

- the density of transport routes;

- the number of types of transport;

2) communication:

- availability of mobile communications;

- availability of the Internet;

3) attitude towards tourists.

The offered structure and content of factors is the basis for formation of specific indicators by which a comparative assessment of the attractiveness of territories for tourists will be made. For each indicator from the group of attracting factors, the result obtained 
relative to the studied area will be compared by objects for comparison according to the formula:

$$
\mathrm{K}_{\text {Опп }}=\sum_{z-1}^{n} \frac{\Pi_{\Pi z i}}{\Pi_{\Pi z j}} \text {, where }
$$

$\mathrm{K}_{\text {опп }}$ - the coefficient of relative attractiveness by attracting factors;

$\Pi_{\Pi z i}$ - the value of the attractiveness of the studied region in terms of attracting factors in terms of $\mathrm{z}$;

$\Pi_{\Pi z j}$ - the value of the attractiveness of the region, which is the base for comparison, by attracting factors in terms of $z$;

$\mathrm{n}$ is the number of indicators by attracting factors.

For the factors that ensure the quality of stay and ensure accessibility, the reference value of the indicator will serve as the basis for comparison, since the perception of them by the tourist is assessed in terms of an acceptable level of comfort. Therefore, the following formulas will be used:

$$
\mathrm{K}_{\text {Опо }}=\sum_{z=1}^{n} \frac{\Pi_{0 z i}}{\Pi_{0 z \ni}} \text {, where }
$$

$\mathrm{K}_{\text {опо }}$ - the coefficient of relative attractiveness of factors providing quality of stay;

$\Pi_{\mathrm{Ozi}}$ - the value of the attractiveness of the factors providing the quality of stay in the studied region according to the criterion $z$;

$\Pi_{0 z \ni}$ - the reference value of the factors ensuring the quality of stay according to $\mathrm{z}$ criterion; $\mathrm{n}$ is the number of indicators for the factors ensuring the quality of stay.

$$
\mathrm{K}_{\text {Опд }}=\sum_{z=1}^{n} \frac{\Pi_{\text {Дi }}}{\Pi_{\text {Дэ }}} \text {, where }
$$

$\mathrm{K}_{\text {опд }}$ - the coefficient of the relative attractiveness of the factors providing the availability;

$\Pi_{Д z i}$ - the value of the attractiveness of the factors providing the availability of the studied region according to $\mathrm{z}$ criterion;

$\Pi_{Д z э}$ - the reference value of the factors ensuring the availability according to z criterion; $\mathrm{n}$ is the number of indicators for factors providing accessibility.

It is offered to form an integral indicator of the region's relative attractiveness using the following formula:

$$
I_{i}=\mathrm{K}_{\text {опп }}+\mathrm{K}_{\text {опо }}+\mathrm{K}_{\text {опд }}
$$

Therefore, use of the offered author's methodology makes it possible to obtain an integrated assessment of the relative attractiveness of the territory, which will make it possible to predict the likelihood of tourists visiting it in comparison with other selected destinations.

\section{Discussion}

The formulated approach to development of a monitoring model has a significant advantage over analogues, the analysis of which was provided in detail in Table 1. The fundamental difference between the offered approach to assessing the attractiveness of a tourist destination lies in formation of a system of relative indicators that clearly demonstrate the differences in the selected parameters in comparison with the territories selected for analysis. The formed system of metrics aims to emphasize the fact that territories with different natural conditions and unique cultural manifestations that will make it possible to get memorable travel impressions will be the most attractive for the consumer of tourist services. Therefore, the offered approach comes from different consumer needs in the field of domestic tourism. Wherein, the number of variables considered is not large, which makes each of them significant in the course of the assessment.

As a result, the local executive authority has data on the level of attractiveness of the territory for specific categories of tourists, which allows concentrating efforts on attracting 
them to the region, effectively directing investment flows to development of problematic elements of the tourist potential in accordance with market demands.

\section{Conclusion}

As a result of the study, some gaps in the methodological support for assessing the attractiveness of tourist areas were identified. Namely, absence of the principle of subjectivity in the process of determining the level of this attractiveness was noted, which leads to ignoring the difference in the motivation and preferences of consumers of tourism services in the course of the analysis, and, therefore, limits the possibilities of promoting the destination. Also, in terms of the approaches considered, excessive use of expert assessments and a large number of parameters by which the tourist attractiveness of the region is assessed is noticed. The offered author's development is an attempt to neutralize these shortcomings by using a limited number of the most significant assessment parameters that have an objective characteristic. The relative form of their accounting in the integral indicator reflects the difference in the actual state of this element of the attractiveness of the location in comparison with the territories selected for comparison, which gives the basis to formation of programs for development of regional tourism considering the demand of consumers for an estimate of the usual situation and obtaining new impressions. Therefore, it becomes possible to develop tourism in territories that have traditionally become unpromising in this regard. This provides opportunities for new conceptual understanding from the point of view of the management of the regional tourism industry.

\section{Acknowledgment}

The study was carried out with the support of the regional state autonomous institution Krasnoyarsk Regional Fund for Support of Scientific and Scientific and Technical Activities within the framework of the project: "Development of an Information and Analytical System for Monitoring the State and Assessing the Development Potential of the Tourism Industry in the Krasnoyarsk Territory for Preparation of Strategic Management Decisions", application code No. 2021021007411.

\section{References}

1. Statisticheskij byulleten' Rosstata k Vsemirnomu dnyu turizma - 2021 (2021). URL: https://docviewer.yandex.ru/view/15133979/?*=a4JD5K2\%2B2cSAGLqsjedGIF24b8 R7InVybCI6InlhLWJyb3dzZXI6Ly80RFQxdVhFUFJyS1JYbFVGb2V3cnVMektMT WhnZkU3cUtUb0xFTHlvcUZVQ1JmRENzV3N5a0Q3cXFHVDJyM0FZT3FMV0pr YVR5LXp1ZVN5eEM5aUdOZF9GZkFFTUZILVBDeFFIa09wYWV2RC1vYmRnQ 1FxbWRneV8tRFU5VWNjc3QxaEkzbEZYZUY3NVpCemhOLUxjM3c9PT9zaWduP VBEb0ZzTG1zUENHZy1PZ3NkMTNIbS1uRHpScFZTSWJLZGZvdTh4YUlxaWc9I iwidGl0bGUiOiJ0dXJpem0tMjAyMS5kb2N4Iiwibm9pZnJhbWUiOmZhbHNILCJ1a WQiOiIxNTEzMzk3OSIsInRzIjoxNjM1MTUyOTA4NzYxLCJ5dSI6IjIwOTA0Mzc4 NDE2MzQ3MDAxNzEifQ\%3D\%3D

2. Rekomendacii po prezentacii turistskogo brenda regiona (2021). Access mode: https://eurasianeconomic.org/document4558.phtml

3. M. A. Sarancha, Turistskij potencial territorii: problematika opredeleniya sushchnosti $i$ struktury, Vestnik Udmurtskogo Universiteta, 25 (1), 134-140 (2015). Access mode: 
https://cyberleninka.ru/article/n/turistskiy-potentsial-territorii-problematikaopredeleniya-suschnosti-i-struktury/viewer

4. D. G. Mamraeva, L. V. Tashenova, Metodicheskij instrumentarij ocenki turistskorekreacionnogo potenciala regiona, Ekonomika regiona, 16 (1), 127-140 (2020). Access mode: https://elar.urfu.ru/bitstream/10995/92054/1/2020_16_1_010.pdf

5. E. I. Bogdanov, Planirovanie na predpriyatii turizma (2005)

6. E. I. Yuvanen, Yu. D. Shmidt, Ocenka rekreacionno-turistskoj privlekatel'nosti territorii, Prakticheskij marketing, 10, 23-27 (2006). Access mode: https://cyberleninka.ru/article/n/otsenka-rekreatsionno-turistskoy-privlekatelnostiterritorii

7. I. S. Glebova, Analiz turisticheskoj privlekatel'nosti goroda $i$ vozmozhnosti ee povysheniya (na primere g. Kazani), Uchenye zapiski Kazanskogo gosudarstvennogo universiteta, 152 (4), 214-227 (2010)

8. E. V. Frolova, E. E. Kabanova, Faktory razvitiya turisticheskoj privlekatel'nosti municipal'nyh obrazovanij Rossii, Voprosy gosudarstvennogo i municipal'nogo upravleniya, 3, 112-128 (2017). Access mode: https://vgmu.hse.ru/data/2017/10/06/1159546837/Фролова,\%20Кабанова\%203$\underline{2017 . p d f}$

9. Indeks turisticheskoj privlekatel'nosti regionov Rossii (2021). Access mode: https://tourism-index.strelka-kb.com/

10. N. I. Danilova, Turisticheskij sektor Rossijskoj ekonomiki v period vseobshchego krizisa 2020 goda. Perspektivy vosstanovleniya turindustrii v Rossijskoj Federacii, Vestnik associacii vuzov turizma i servisa, 2-1, 4-10 (2020)

11. M. V. Gudkovskih, Metodika kompleksnoj ocenki turistsko-rekreacionnogo potenciala, Geograficheskij vestnik, 1 (40) (2017). Access mode: https://cyberleninka.ru/article/n/metodika-kompleksnoy-otsenki-turistskorekreatsionnogo-potentsiala

12. A. N. Dunec, E. P. Krupochkin, A. A. Tel'cova, Ocenka turistsko-rekreacionnogo potenciala dlya celej territorial'nogo planirovaniya, Izvestiya AltGU, 3-2, 108-113 (2011). Access mode: https://cyberleninka.ru/article/n/otsenka-turistskorekreatsionnogo-potentsiala-dlya-tseley-territorialnogo-planirovaniya

13. L. I. Kulakova, V. A. Osipov, Metodicheskie podhody $k$ ocenke turistskorekreacionnogo potenciala rossijskih regionov, Rossijskoe predprinimatel'stvo, 24 (2017). Access mode: https://cyberleninka.ru/article/n/metodicheskie-podhody-kotsenke-turistsko-rekreatsionnogo-potentsiala-rossiyskih-regionov

14. U. A. Zagumennaya, Sovremennye problemy i perspektivy razvitiya arkticheskogo turizma $v$ Rossii, Aktual'nye problemy gumanitarnyh i estestvennyh nauk, 11-7 (2015). Access mode: https://cyberleninka.ru/article/n/sovremennye-problemy-i-perspektivyrazvitiya-arkticheskogo-turizma-v-rossii

15. L. Yan, B. W. Gao, Z. Meng, A mathematical model for tourism potential assessment, Tourism Management, 63, 355-365 (2017)

16. G. Sahin, M. Kahraman, An Evaluation about Hakkeiri's Tourism Potentials, Journal of geography-cografya dergisi, 34 ,1-21 (2017)

17. D. Mihaila, P. I. Bistricean, A. E. Briciu, Assessment of the climate potential for tourism, Theoretical and applied climatology, 137 (1-2), 601-622 (2019) 
18. L. T. An, J. Markowski, P. Namiecinski, An evaluation of destination attractiveness for nature-based tourism: Recommendations for the management of national parks in Vietnam, Nature conservation, 32, 51-80 (2019) 